University of Wollongong

Research Online

Faculty of Law, Humanities and the Arts Papers (Archive)

Faculty of Arts, Social Sciences \& Humanities

$1-1-2019$

Exoticism or visceral cosmopolitanism: difference and desire in Chinese Australian women's writing

Wenche Ommundsen

University of Wollongong, wenche@uow.edu.au

Follow this and additional works at: https://ro.uow.edu.au/lhapapers

Part of the Arts and Humanities Commons, and the Law Commons

Research Online is the open access institutional repository for the University of Wollongong. For further information contact the UOW Library: research-pubs@uow.edu.au 


\title{
Exoticism or visceral cosmopolitanism: difference and desire in Chinese Australian women's writing
}

\author{
Abstract \\ In Visceral Cosmopolitanism, Mica Nava posits a positive and, by her own admission, utopian alternative \\ to postcolonial readings of the sexualisation of difference: a cosmopolitanism located with the antiracist \\ 'micro-narratives and encounters of the emotional, gendered and domestic everyday' (2007: 14). Olivia \\ Khoo, in The Chinese Exotic, defines a new, diasporic Chineseness which 'conceives of women and \\ femininity, not as the oppressed, but as forming part of the new visibility of Asia' (2007: 12). My reading of \\ recent fiction by Chinese Australian women writers proposes to test these theories against more \\ established models for understanding East/West intimate encounters such as exoticism, Orientalism and \\ Occidentalism, speculating that they may offer a more nuanced understanding of both the complexity and \\ the normalisation of difference in the affective cultures of the twenty-first century.

\section{Disciplines} \\ Arts and Humanities | Law

\section{Publication Details} \\ Ommundsen, W. "Exoticism or visceral cosmopolitanism: difference and desire in Chinese Australian \\ women's writing." Journal of Intercultural Studies 40.5 (2019): 595-607.
}




\title{
Exoticism or Visceral Cosmopolitanism: \\ Difference and Desire in Chinese Australian Women's Writing
}

\author{
Wenche Ommundsen \\ University of Wollongong \\ wenche@uow.edu.au
}

\begin{abstract}
In Visceral Cosmopolitanism (2007) Mica Nava posits a positive and, by her own admission, utopian alternative to postcolonial readings of the sexualisation of difference: a cosmopolitanism located with the antiracist 'micro-narratives and encounters of the emotional, gendered and domestic everyday'. Olivia Khoo, in The Chinese Exotic (2007) defines a new, diasporic Chineseness which 'conceives of women and femininity, not as the oppressed, but as forming part of the new visibility of Asia'. My reading of recent fiction by Chinese Australian women writers proposes to test these theories against more established models for understanding East/West intimate encounters such as exoticism, Orientalism and Occidentalism, speculating that they may offer a more nuanced understanding of both the complexity and the normalisation of difference in the affective cultures of the $21^{\text {st }}$ century.
\end{abstract}

\section{Keywords}

Visceral cosmopolitanism; everyday cosmopolitanism; Chinese exoticism; Orientalism; diasporic Chinese identities; the sexualisation of difference 
Australia's Asian-born population, at $8 \%$, is twice that of the US and four times that of the UK as a share of the total population (Ang et al, 2015: 16). It is important to note, however, that mass migration of Asians into Australia is a relatively recent development: as a consequence of the White Australia policy which remained in place until the 1970s, very few Asian migrants were accepted into the country before then: the large-scale post-World War II migration program primarily targeted European migrants. This means that a very high proportion of Australia's Asian population, and of the writers among them, are firstgeneration migrants, and it is only in the $21^{\text {st }}$ century that writers of the second generation have emerged. It also means that in spite of Australia's increasingly multicultural and multiracial population, the notion of whiteness as determinant of national identity is a very recent memory, an attachment to which regularly surfaces in media and political discourse. While the far-right politician Pauline Hansen's fear of being 'swamped by Asians' in recent years has changed to fear of 'being swamped by Muslims', racism towards all visual minorities is on the rise and has been given greater legitimacy in recent years, in Australia as in other parts of the world. Anti-Chinese attitudes have also been reinforced through current concerns about China's growing influence in the region and in the world. Inter-racial encounters of all kinds are becoming part of the daily lives of most Australians at the same time as they, and particularly the Asians among them, are acutely sensitised to cultural tensions which pit a multicultural, cosmopolitan Australia against older models of cultural as well as geographical insularity. Within this somewhat paradoxical cultural climate it is hardly surprising that orientalist constructions of race and gender have retained some of their currency, and that they remain a key preoccupation for Australian writers, especially Asian Australian writers. 
This essay offers examples of texts by women writers of Chinese background who deal centrally with intimate relationships between Chinese and non-Chinese partners, speculating on how they negotiate the cultural, racial and sexual preconceptions thrown up by these affairs. ${ }^{1}$ And while theoretical models for understanding inter-racial sexual relations have primarily focused on orientalist (and sometimes occidentalist) models for understanding links between difference and desire, I consider these alongside alternative readings such as neo-exoticism and visceral cosmopolitanism. It needs to be noted, however, that the very notion of 'Chinese' covers a wide range of meanings in diaspora, variously deployed in relation to nationality, ethnicity or culture. In popular discourse 'Chinese' often becomes virtually interchangeable with 'Asian' or 'East Asian'. This means that 'Chineseness' can never be taken for granted and its usage always needs to be interrogated and nuanced, as indeed do ethic/national markers such as 'Western', 'white' or 'Australian' .2 The writers considered in this essay illustrate the diversity of backgrounds assembled under the general label 'Chinese': Isabelle Li was born in Mainland China and came to Australia via Singapore; Cher Chidzey was born in Singapore; Melanie Cheng was born in Australia of mixed heritage (Hong Kong father, (white) Australian mother) but grew up in Hong Kong. Michele Lee was also born in Australia. Her family came to Australia from Laos, but their ethnic background is Hmong, a sub-group of the minorities known in China as Miao, who trace their origins to Southern China. In choosing the term 'Chinese' rather than the equally ambiguous 'Asian' to designate these writers, I am mindful of Ien Ang's contention (2001) that the use of this ethnic/national marker in diaspora often says less about their actual origins than it does about an identity projected onto them by the mainstream culture.

Chinese Australian writing has from the very beginning been centrally concerned with gender relations and the status of women, in society as well as in intimate relationships. Echoing the pro-Western and anti-patriarchal discourse common in China in the period 
leading up to the republican revolution of 1911 and the May $4^{\text {th }}$ Movement of 1919, Chinese language newspapers in Sydney and Melbourne in the first decades of the $20^{\text {th }}$ century were publishing literary texts as part of their campaign to educate the lower classes in the diasporic community. The traditional Chinese practices of polygamy and foot-binding were strongly condemned and women's illiteracy and lack of agency in the family deplored. The aim was to urge members of the community to leave behind customs that were thought to stand in the way of China's path towards modernisation as well as damage the reputation of the Chinese in diaspora. ${ }^{3}$ Indeed, the very first Chinese Australian novel, published in instalments in Melbourne's Chinese Times from 1909 to1910, had an overtly feminist message. Titled The Poison of Polygamy, the novel details the adventures of the anti-hero Huang Shang-Kang who travels from Guangdong to Australia in the middle of the $19^{\text {th }}$ century in search of gold. Shang-Kang is not only lazy, incompetent and dishonest, he is also an opium smoker, a polygamist and a cruel husband, and, even before he gets his just deserts, roundly condemned by the intrusive narrator. While it can be argued that the novel's attack on the misogynist practices of traditional Chinese culture is undermined by its portrayal of female characters straight out of the patriarchal textbook, this novel serves as a useful reminder that the Chinese reformist agenda in the years leading up to the republican revolution of 1911 and the May $4^{\text {th }}$ Movement took as one of its key targets the oppression of women within the marital economy. ${ }^{4}$ This agenda was echoed in diaspora, and newly founded newspapers such as The Tung Wah Times in Sydney and Chinese Times in Melbourne published literary texts as well as opinion pieces blaming practices such as polygamy and foot-binding for China's backwardness in relation to the rest of the world. Apart from The Poison of Polygamy, there were short stories such as 'New Conjugal Relations', published in The Tung Wah Times (Sydney) in 1906, which featured conflicts between an older husband and a young wife who demands greater equality in marriage. There were also stories portraying strong and clever 
women, such as 'A Woman Detective - Ms Lotus Flower', published in four instalments in The Tung Wah Times in 1910. This reform agenda is particularly interesting given the vast gender imbalance in the diasporic community: in 1901 there were, according to Brian Murphy, only 394 women of Chinese birth in Australia (1993: 36).

As a result of the White Australia policy (1901), which effectively banned the entry of non-European migrants, the Chinese community decreased dramatically in the first half of the $20^{\text {th }}$ century, and the Chinese language press declined and eventually ceased altogether. Literary writing by Australians of Chinese descent did not appear again until around 1980, following the abandonment of the White Australia policy and the first waves of Asian migrants, initially from South East Asia. These writers wrote in English, but the late 1980s and 1990s saw a large intake of migrants from mainland China, and a renaissance of Chinese language publications. Recent decades have seen continued strong migration from both mainland China and other countries with ethnic Chinese populations, to the point that Mandarin is now the second most spoken language in Australia, and Cantonese the fourth. Writing in Chinese has declined somewhat since its heyday of the 1990s, but recent years have seen a blossoming of writing in English by Chinese Australian writers, most of them women. Gender roles and gender relations feature prominently in this writing, often serving as markers of cultural difference. And like their predecessors in the early $20^{\text {th }}$ century, some in these recent generations of writers use their writing to attack the misogyny they see as inherent in Chinese culture up to the present.

Postcolonial theory has convincingly argued for the inextricable link between race and gender, for the tendency to sexualise racial difference, and to eroticise otherness (Nava 2007: 71). Within orientalist discourses, this generally takes the form of exoticism, in which racial others (most often women) are represented as objects of sexual desire. More recently, theorists casting women as subjects rather than objects have pointed to shortcomings in the 
orientalist model, particularly in the analysis of the affective cultures of the increasingly cosmopolitan societies of the $21^{\text {st }}$ century. In her book The Chinese Exotic, Olivia Khoo offers a different reading of exoticism when she defines a new, diasporic Chineseness which 'conceives of women and femininity, not as the oppressed, but as forming part of the new visibility of Asia.' (2007: 12) Within the new economies of desire in which Asia is represented as cosmopolitan, rich, modern and technological, exoticism is produced as 'repetition with a difference' (72). The repetition can take the form of inversion, as in the film Chinese Box in which the Madame Butterfly theme is reversed so that the exotic female survives and the Western male dies, or it can make the Chinese exotic hypervisible and larger than life, taking the form of femme fatale, spy, vampire or woman warrior. Khoo comments on the double, often paradoxical effect of these new modes of exoticist representation: on the one hand they offer possibilities of subject positions and positive agency for Asian women, on the other they cannot entirely escape their orientalist and sexist underpinnings:

\footnotetext{
Despite competing visions, strategic reformulations of previous discourses and historical, geographical and theoretical variations, the structural and semantic core of exoticism remains that of feminine difference and a dominating masculine desire; this is the story that sells and is therefore repeated. (22)
}

In her reading of an earlier cosmopolitan society, London before and during World War II, Mica Nava in Visceral Cosmopolitanism similarly notes the insufficiency of postcolonial, orientalist models to account for the range of representational and emotional articulations of cross-racial interactions within everyday, domestic culture (2007: 6-7). With a focus on 'the unconscious, non-intellectual, emotional, inclusive features of cosmopolitanism, on feelings of attraction for and identification with otherness' (8), she by contrast wants to claim the erotic attraction of racial others, in this case white women's desire for and sympathy towards non-white men, for anti-racism, for an affective culture of resistance and transformation. Admitting that hers is 'a largely positive and utopian reading of twentieth-century cosmopolitanism' (15), she insists that it should stand alongside 
orientalist xenophobia as an alternative response to transnational encounters within the domestic sphere. Attempting to understand the psychological factors behind what she calls women's 'inclusivity and eroticised identification with difference' (64), she links the oppression of black men with the oppression of women, and points to women's weaker attachment to exclusivist notions of 'nation' and greater orientation towards the idea of a whole, cosmopolitan world. Her argument echoes ideas espoused by theorists of 'everyday' and 'vernacular' cosmopolitanism who argue for a more nuanced reading of cosmopolitan cultures taking into consideration class and gender as determinants of race relations. Sneja Gunew defines Nava's project in the following terms:

\footnotetext{
Her point (and I'm simplifying) is that by gendering received notions of colonialism and orientalism, a cultural anthropologist or historian/sociologist can produce a different picture of colonial and interracial relations during that period. (2017: 31)
}

Before commenting on some of the most recent accounts of inter-racial intimacy in Chinese Australian women's writing I want to revisit a debate that raged in the Chinese language press in Sydney in the 1990s. It started in 1994, when Shi Guoying, a recent migrant from mainland China, published an article in a monthly Chinese language magazine entitled 'Are women who married Australian men happy?' Here she makes the provocative claim that

\footnotetext{
Western men who are excellent love makers are everywhere. Out of every ten Western men, at least eight are terrific and only two are average. Out of every ten Chinese men, two are average and eight are pathetic. (2002: 146-147)
}

Not surprisingly, this sparked a fierce debate which also spilt over into English language media. Shi's supporters, most of them women, denounced Chinese men as sexually incompetent misogynists, her opponents, mostly men, argued that Shi had fallen victim to tired Western stereotypes and condemned her of cultural betrayal. Accusations of orientalism and occidentalism flew back and forth to the bewilderment and amusement of observers, who dubbed the controversy 'a storm in a Chinese tea-cup.' (Zhong 2001: 57) The theme was 
repeatedly echoed, with variations, in the literary writing of the time, such as Shi Guoying's own novella 'Mistaken Love' (1999), in which the protagonist compares her three lovers, one Chinese, one French and one Australian. Critics have pointed out that the idealisation of Western men has been a constant theme in the work of Chinese women writers at least since the time of the May $4^{\text {th }}$ Movement, revived by feminist writers since the 1970 s who in their condemnation of Chinese patriarchy have frequently held up Western men as both more egalitarian and more attentive to women's sexual needs ${ }^{5}$.

The Chinese language writers of the 1980s and 1990s were recent migrants whose exposure to Western culture had been and often remained minimal. Many of them had limited English and most faced considerable financial hardship which forced them to work in menial jobs to survive in Australia and pay off debts. They wrote for and about their own community, projecting onto their host country their own aspirations while rejecting aspects of Chinese culture and society. Their idealisation of Western men was a product of Chinese feminist thinking while at the same time reflecting their desire for greater interaction with a society in which integration proved difficult for many. The protagonist of Jin Xin's novella 'The Australian Lover' acknowledges the complexity in her attitude to her white lover and puts it in these terms: 'Maybe what I love is not you but the ideal life embodied by you that we have travelled a long distance to pursue (1999: 26-27).

Moving forward some twenty years to the most recent literary writing by Chinese Australian women, we observe major changes echoing the different positions occupied by the authors in relation to both China (or more generally, cultural Asia) and Australia. Recent migrants come with a different personal background, different aspirations and a very different sense of China's position in relation to the rest of the world. While there has been a blossoming of writing by women of Chinese background in recent years, most of it has been in English, and most of the writers are from a non-mainland background (Singapore, 
Malaysia, Australian-born, etc.). These writers occupy a different cultural space, more cosmopolitan, reflecting both the rapid changes in their home countries and greater familiarity with Western and Westernised societies. They have retained the keen interest in the intersection of race, gender and sex which characterised the work of the previous generation, but their perspective is different. Stereotypes of East/West sexual relations commonly surface, but when they do, they tend to be held up for scrutiny, viewed from different cultural angles, played with, and shown to be much more complicated than in the writing of the 90s. Aspects of Khoo's reimagined 'Chinese exotic' do battle with a visceral cosmopolitanism that echoes at the same time as it defies earlier models for sexual/racial encounters thrown up by postcolonial theory.

Ken's Quest, the first novel by Singapore Australian Cher Chidzey, published in 2016, revisits the predicaments of mainland migrants of the early 1990s but unlike most earlier texts, depicts a relationship between a Chinese man and an Anglo Australian woman. Her main character Wei Da, a widowed Shanghai engineer who calls himself Ken in Australia, has arrived on a false passport in a quest for a better life for himself, his mother and children. The shortcut to such a life is marriage: 'he was on a mission to fall in love, get married and obtain permanent residency.' (20) After a couple of failed attempts with Chinese Australian women, he develops a relationship with his English teacher, Julia, a relationship which will change the nature of his quest and force him to question his previous attitudes towards women, towards Australia, towards China and towards himself. Midway through Ken's sentimental re-education, the narrative focus shifts to Julia. Julia is well off, but emotionally bereft: her parents were killed in an accident when she was thirteen. Like Ken, her former lovers have been Asian. The first, a Thai youth called Patee, has convinced her 'that dark-skinned men had supreme sexual prowess.' (115) The second, Chew, a Chinese Malaysian, was sexually inept, but spiritually powerful. Both have betrayed her: Patee went 
through most of her inheritance and Chew disappeared without a trace. Her attitude to Ken is mixed: she swears that she will not be taken advantage of by another man, but she is strongly attracted to him, as he is to her. Julia in many ways typifies the psychological factors identified by Mica Nava as most conducive to eroticised identification with difference: a sense of inferiority linked to her gender, a privileged, but emotionally deprived upbringing (Nava 69-71). In her case, however, there is a suggestion that this attraction may be pathological. Her Asian men are likened to food: Patee is 'chocolaty' (115) and Ken's skin is like honey, making her want to lick him. But Julia has an eating disorder: food has become a way of satisfying her emotional needs and as a consequence she is very overweight. Her sexual attraction to Asian men could thus be interpreted as a symptom of a psychological dysfunction. Her re-education, initiated by Ken, includes developing a healthier relationship with food and by extension, a re-examination of her feelings for her Asian lovers. The novel ends on Ken's departure from Australia after both lovers decide that they need to rethink their motivations: Ken no longer looks to marriage as a shortcut to Australian residence and Julia has to re-examine the nature of her attraction to him. There is, however, a strong suggestion that their relationship has a future, based on an evolving personal and transcultural understanding which reaches towards togetherness beyond the stereotypes and psychological baggage each of them has brought to the union. 'Real gold will withstand fire as real love will withstand separation,' (204) is Ken's final promise to Julia as he boards his plane for Shanghai.

Banana Girl (2013) is a memoir by Michele Lee, Australian-born daughter of Hmong migrants. Michelle's family migrated to Australia from Laos, not China, but the minority group they belong to, a sub-group of the minorities now known in China as Miao, trace their origins to Southern China, which is why I have chosen to include Lee within my, admittedly loose, definition of 'Chinese' for the purpose of this paper. Banana Girl was written when 
Lee was 29 years old, mostly in the form of letters to her 15-year old self. While such letters would normally contain advice from an older and wiser person, this memoir is mostly defensive, justifying and explaining a life-style the 15-year old would not have approved. Michele is, by her own confession, 'emotionally retarded.' (13) Most of her story deals with her complicated sex life, her relationship with her four long-term boyfriends and numerous other sexual partners. After a teenage 'crusade against all things Hmong' (22) she has 'escaped down south' (6) to the fashionable inner Melbourne suburb of Brunswick, where she lives a bohemian life on the fringes of the city's art scene, hanging out in bars and taking casual lovers home to her share-house. Michele knows that her 'golden banana skin' (8) is attractive to her white lovers, who consider her 'cool' (56), 'interesting' (235), and 'exotic' (92), but also that many are frightened of her, that she has the reputation of being a 'maneater.' (32) Michele is seemingly without sexual inhibitions: not only indiscriminate in inviting casual acquaintances into her bed, but also freely entertaining current lovers with details of sexual exploits with their predecessors. A heavily ironic tone reveals her awareness of her own contradictions: longing for romantic love and a stable relationship while behaving in a way that fascinates her partners, but scares them off: 'how is it even possible that I can experience giddy hope and hot rejection when I'm obviously just a robot programmed to be on a permanent auto-fuck setting.' (139) And while Michele recognises that her boyfriends' attitudes are, at least in part, shaped by preconceptions about Asian women, she freely admits to her own racial biases, in particular her preference for white men. Of an Asian acquaintance and potential lover she writes:

He had a happy round face but it was a yellow face and he was Asian and I didn't have sex with Asian guys or non-white guys and I never had and I never would and please don't make me.' (219)

Michele's banana image is complex: she confronts, at the same time as she ironically reincarnates sexual and ethnic stereotypes in the world of Gen Y hipsterdom. Part mockery (and self-mockery), part sincere, her memoir offers a stark example of Olivia Khoo's 
'cosmopolitan, neo-exotic Chinese subjects' (66): repetition with a difference that at the same time appropriates, challenges and re-encodes ethnic fantasies born of a colonial (and sexist) culture. Her rejection of Asian men, unlike that of Shi Guoying, is not explicitly based on a perception of them as being inferior in terms of sexual performance, nor does she directly extol the sexual prowess of her white partners. Her sexual preferences seem to be an extension of her cultural trajectory: rejection of the sexual/marital economy of the Hmong community, bid for acceptance within the segment of progressive urban culture she dubs 'Theatre Land'. It becomes a statement, not about individuals, but about a personal or collective past she wants to leave behind. In her recent memoir UK-based writer Xiaolu Guo explains her own preference for white partners:

[O]ne thing was clear to me: I didn't want to date another Chinese man ever again. It's not that I was against Chinese men and couldn't see that some were attractive, intelligent or interesting. I wasn't that superficial. It was the culture of masculinity in China that I was revolting against, a fact that was inextricably linked to all my bad experiences with the old traditions. (Guo 2017: 213)

Unlike Guo, Michele Lee does not seem to have personal experience of Asian partners behaving badly; to her, it is the culture they represent she rejects. Self-identifying as a banana, she is also acutely aware of her contradictions, and on occasion also calls out racial prejudice against Asians in mainstream culture. While mocking the exoticism projected onto her, Lee can nevertheless be seen as a version of the paradoxical diasporic identity Khoo identifies as the new 'Chinese exotic', an identity which affords her a degree of power over her partners at the same time as it stands in the way of her developing the emotional maturity required for sustainable intimate relationships.

Isabelle Li, who migrated from mainland China to Australia via Singapore, revisits similar dilemmas in her short story collection A Chinese Affair (2016). Many of the stories are linked through the character of Crystal, a migrant from mainland China who has come to Australia as an interpreter and married a much older Australian man, but who finds herself 
pregnant to her lover, a Chinese artist. Crystal's life is told in segments, going back in time from the discovery of her pregnancy to the recent past and to her childhood in China. This technique allows the author to experiment with different perspectives as well as different attitudes to similar issues. For example, Crystal is sometimes shown to play along with the images projected onto her as a Chinese woman, as when she dons a traditional costume at a writers' festival: 'There seems to be some decorative value in a Chinese costume, which makes me feel like a porcelain vase, exquisite and brittle, to be treated with care...' (7) Similarly, with her husband and his adult children, she plays the role of 'his inscrutable oriental muse' (9), returning their rather patronising affection with amused tolerance:

they share a collective comical affection for me. My comments are exotic, amusing, controversial and not to be taken seriously... I can afford to be controversial. I can blink my almond-shaped eyes and make provocative statements to people's faces. (8)

Sometimes, however, the mask drops, as for example when she feels a need to correct their ill-informed comments on China's one child policy. In another story, Crystal adopts another attitude when people insist she should use her Chinese name because it's 'very special': 'I do not want to be special. I am not an exotic bird and have no interest in showing off my plumage.' (105)

Crystal's relationship to the men in her life could be seen to reverse the 'white lover' theme of so much earlier fiction. Her Australian husband is a benevolent, safe anchor in her life, their relationship based on mutual affection rather than sexual attraction. He is represented as 'subdued and reliable' (7), and he is sterile, having had a vasectomy after the birth of his three children to his first wife. Her lover Lin, by contrast, is young and handsome. In Crystal's mind, he is associated with art and nature, evoked through touch and smell: 'his mouth was always soft and moist. An oasis in the desert, she thought, or a tropical fruit with white seeds and sweet essence' (33). He is described as being at the same time sensual, exotic and intensely familiar, reminding her of her childhood and their common culture but also of something rare, precious and erotic. While there is a juxtaposition of an Australian man and a 
Chinese man in Isabelle Li's text, they are never directly compared; instead the author assigns different attributes to them. Crystal's Australian husband gives her care, warmth and familial security whereas her Chinese lover satisfies both her sexual and spiritual needs, including her nostalgia for her hometown. Both men are successful in their careers and both deserve her love. In Li's text, racial stereotypes are frequently invoked, but they do not inform the portrayal of her characters. By representing the lover as sexually attractive and fertile as well as caring, Li could be seen to subvert the 'Chinese man/Western man' dichotomy constructed by Shi Guoying and her supporters. However, there is little to suggest that this is the motivation behind the portrayal. Cultural stereotyping is frequently on display in these stories, but they are not confined to the Chinese. In fact, most of Li's critique is aimed at white Australians who through ignorance project onto Crystal and her country their own orientalist fantasies.

Li's Crystal is a translator, not only of language but of culture as well. She is keenly aware of cultural sensitivities and the potential for misunderstanding and sees it as her role to smooth over differences. She reflects on the nature of translation, and relishes the power of understanding the dual perspective afforded by her in-between status gives her, but is also aware that it comes at a cost. Her friend Lily suffers acutely from 'the grief that comes from loss of language' (291) and Crystal herself experiences the loss of a firm sense of belonging: 'I wonder who I am, why I am here...As if walking in a snowstorm, I look back to find that my footprints have been erased. I do not know where I am and can no longer find my way back'

'Australia Day', the first story in Melanie Cheng's debut collection by the same name, also features a triangle, in this case an Australian girl and her two boyfriends, one Australian, the other from Hong Kong. Cheng, who was born in Australia but grew up in Hong Kong, may have loosely based the story on the experience of her parents, who met as medical 
students in Australia. The story is told in the third person from the perspective of Stanley Chu, who has been invited to spend the Australia Day holiday with the family of his friend and fellow student, Jessica. Against the backdrop of a quintessential 'Aussie' country family and their barbecue of meat, potato salad, sausages, white bread and large quantities of beer, Stanley reflects on his own lack of belonging, and on his relationship with Jessica '(who is not yet your girlfriend, but who you hope, some day, might be).' (12) Also a guest at the party is Jessica's former boyfriend, Eddie, who is 'good-looking (in a goofy, barefoot, Queensland kind of way)' (3) but who has cheated on Jessica with another woman. Stanley knows he cannot compete with the handsome, easy-going, popular Eddie, but makes his own bid to fit into the rather alien culture of his adopted country (he has recently become a citizen) by ignoring slights, drinking beer and offering self-deprecating jokes such as "“Chinese people eat everything with four legs...except the table."” (7) When he hears that Eddie has broken up with his new girlfriend, he assumes Jessica will take him back. However, while the story does not reveal the outcome of their relationship, there is a strong suggestion that Stanley, in his defensiveness and sense of masculine inferiority, is misreading Jessica. When she comes into his bed at night, offering intimacy, he is afraid to show his arousal, and they end up sleeping together without having sex. The suggestion is that Stanley's over-sensitivity about his own cultural and physical difference makes him incapable of reading the feelings of other characters, not only Jessica's preferences, but also her, and her brother's, embarrassment about the whole performance of traditional 'Australianness' represented by the Australia Day barbecue. Jessica's tattoo of the Chinese character for double happiness, her annoyance with both him and Eddie at the end of the party, could be read as hints that in this particular triangle, it is not the Chinese man who will come out the worse off. The focus of the story is not primarily, however, on who wins the girl, but on Stanley's inhibitions, seemingly caused by stereotypical notions of both Asian 
and Caucasian masculinity and their effects on individuals as they enter the uncharted waters of cross-cultural intimacy.

These examples of heterosexual relations between Asian and Caucasian Australians as portrayed in recent writing by Asian Australian women differ considerably between them and it would be hazardous to generalise on the basis of this small sample. They all, however, offer insights into the kind of negotiations, and the kind of tensions, arising within such relationships in contemporary Australia, and can usefully be read in the context of the country's recent history of immigration and rapid changes within the composition of its multicultural society. While it is clear from media debates at the time that many of the Chinese language women writers of the 1990s, who on arrival had little experience of Western culture but strong views on Chinese patriarchal traditions, deliberately idealised Western men to provoke their compatriots and stimulate debate within the diasporic community $^{6}$, the current generation of women writers not only write for a wider readership, but also present views that resonate with a wider range of personal and political concerns. The attitudes and dilemmas presented in their writing constitute active interventions into the debates surrounding the integration of Asians into a society in which they are at the same time welcomed and othered. The cosmopolitanism in these encounters is of an everyday variety, negotiated within the rituals of courtship, sex and marital relations, where cultural and gendered identity merges with individual social and psychological needs to form unique interpersonal configurations. Read in its historical context, this 'everyday' offers fresh perspectives on ongoing negotiations and bear witness to social conflict at the same time as they map social transformation. As Mica Nava writes,

It is increasingly clear...that in relation to cosmopolitanism, as was also the case of secondwave feminism, the personal is political; affective cultures are deeply implicated in political resistance and transformation, in antiracism as much as racism. Gender and structures of feeling - the micro-narratives and encounters of the emotional, gendered and domestic everyday - must be taken into account if we are to understand the specificity of the contemporary context. (14) 
'Resistance' and 'transformation' in these texts take the form of individual struggle with social and cultural norms as they impinge on emotional and sexual lives. From Ken and Julia's quest to overcome personal and cultural baggage standing in the way of their relationship to Stanley's internalised devaluation of his own masculinity, politics takes the form of affective and somatic engagement with difference. From Michele, whose contradictory attitudes to her body, her ethnicity, and her sexual life bear witness to cosmopolitan conflict in the most intimate domain, to Crystal, who ironically re-enacts orientalist fantasies at the same time as she offers acute observations on stereotypes attached to mixed-race couples, the Asian women portrayed in these texts find themselves at the forefront of social and cultural transformation. As agents of social change, however, they steer a fine line between different sets of cultural norms. If, as Olivia Khoo suggests, the concept of cultural China is male-biased and tied to Confucianism, they look elsewhere for a set of values that can accommodate their identities as modern women of Asian descent. Alternating between resistance - rejecting both western and Asian models for gendered ethnicity - and strategic complicity such as the self-conscious, sometimes uncomfortable, harnessing of exoticism, these characters, both male and female, become part of a new diasporic visibility to challenge earlier cultural representations and assume an active role in their reformulation. In so doing, they also serve to decentre cosmopolitanism itself, making room for gendered, cultural and everyday varieties. As Olivia Khoo reminds us,

Cosmopolitanism is neither a western invention nor western privilege. The histories of colonisation and cultural interaction generate multiple, discrepant cosmopolitanisms, partly rooted in local cultures, partly in regional or global networks... (Khoo: 66)

The texts examined in this paper suggest that contemporary Australia, with its unique history, geographic location and ethnic/cultural mix, provides a fertile field for such discrepant cosmopolitanisms of the everyday to evolve. 


\section{Acknowledgements}

This work was supported by the Australian Research Council, the University of Wollongong and the University of British Columbia. 


\section{References}

Ang, Ien, 2001. On Not Speaking Chinese. Living Between Asia and the West. London and New York: Routledge.

Ang, Ien, Tambiah, Yasmin, and Phillip Mar, 2015. Smart Engagement with Asia:

Leveraging Language, Research and Culture. Report for the Australian Council of Learned Academies.

http://acola.org.au/wp/PDF/SAF03/SAF03\%20SMART\%20ENGAGEMENT\%20WIT H\%20ASIA\%20-\%20FINAL\%2010\%20res.pdf

Cheng, Melanie, 2017. Australia Day. Melbourne: Text Publishing.

Chidzey, Cher, 2016. Ken's Quest. Melbourne: Threekookaburras.

Ferrier, Carole, 2017. 'Preoccupations of Some Asian Australian Women's Fiction at the

Turn of the Twenty-First Century', eTropic, 16:2.

https://journals.jcu.edu.au/etropic/article/view/3619/3487

Gunew, Sneja, 2017. Post-Multicultural Writers as Neo-Cosmopolitan Mediators. New York: Anthem Press.

Guo, Xiaolu, 2017. Once Upon a Time in the East. London: Vintage.

Hong Fincher, Leta, 2018. Betraying Big Brother: the Feminist Awakening in China. London: Verso.

Huang, Zhong, 2012. Representation of Chinese Masculinity in Chinese Australian Literature 1978-2008. PhD thesis, University of Wollongong.

Huang, Zhong and Wenche Ommundsen, 2015. 'Towards a Multilingual National Literature:

The Tung Wah Times and the Origins of Chinese Australian Writing', JASAL, 15:3. http://www.nla.gov.au/openpublish/index.php/jasal/article/view/3642/4748

Huang, Zhong and Wenche Ommundsen, 2016. 'Poison, Polygamy and Postcolonial Politics:

The First Chinese Australian Novel', Journal of Postcolonial Writing, 52(5), 533-544. 
金杏. 澳洲情人// 张威, 阿牛. 澳洲情人：澳大利亚中国留学生情爱小说选. 南昌: 百花

洲文艺出版社,1999, 1-35.

[Jin, Xin, 1999. 'The Australian Lover.' In Wei Zhang and A'niu, eds. The Australian Lover: A Collection of Love Stories by Chinese Students in Australia. Nanchang:

Baihuazhou Wenyi Publishing House, 1-35.]

Khoo, Olivia, 2007. The Chinese Exotic: Modern Diasporic Femininity. Hong Kong: Hong Kong University Press.

Lee, Michele, 2013. Banana Girl. Melbourne: Transit Lounge.

Lee, Micheline, 2016. The Healing Party. Melbourne: Black Inc.

Li, Isabelle, 2016. A Chinese Affair. Witchcliffe WA: Margaret River Press.

Louie, Kam, 2001. 'I Married a Foreigner: Recovering Chinese Masculinity in Australia,' in

Wenche Ommundsen, ed., Bastard Moon: Essays on Chinese-Australian Writing.

Kingsbury: Otherland Publications, 39-56.

Louie, Kam, 2002. Theorising Chinese Masculinity: Society and Gender in China.

Cambridge: Cambridge University Press, 2002.

Murphy, Brian, 1993. The Other Australia: Experiences of Migration. Cambridge:

Cambridge University Press.

Nava, Mica, 2007. Visceral Cosmopolitanism: Gender, Culture and the Normalisation of Difference. Oxford and New York: Berg.

Ommundsen, Wenche, 2017. 'The literatures of Chinese Australia,' Oxford Research Encyclopedia of Literature.

http://literature.oxfordre.com/view/10.1093/acrefore/9780190201098.001.0001/acrefo re-9780190201098-e-150

Pan, Lynn, 2015. When True Love Came to China. Hong Kong: Hong Kong University Press. 
Schaffer, Kay and Xianlin Song, 2014. Women Writers in Postsocialist China. Londong and New York: Routledge.

施国英. 错爱// 张威, 阿牛. 澳洲情人: 澳大利亚中国留学生情爱小说选. 南昌: 百花洲 文艺出版社,1999, 214-56.

[Shi, Guoying, 1999. 'Mistaken Love'. In W. Zhang and A'niu, eds. The Australian Lover: A Collection of Love Stories by Chinese Students in Australia. Nanchang, Baihuazhou Wenyi Publishing House, 214-56.]

施国英. 和澳洲西人结婚幸福吗? // 钱超英. 澳大利亚新华人文学及文化研究资料选. 杭

州: 中国美术学院出版社, 2002, 143-48.

[Shi, Guoying. 2002. ‘Are Women Who Married Australian Men Happy?’ In Chaoying Qian, ed. Selected Collection of Research on Literature and Cultural Studies of New Chinese Australians. Hangzhou: The China Academy of Fine Arts Publishing House, 143-48. Original publication 1994.]

Zhong, Yong, 2001. What's Behind White Masks and Yellow Skin: A Postcolonial Critique of a Chinese Sex Debate in Sydney. In Wenche Ommundsen, ed. Bastard Moon: Essays on Chinese-Australian Writing. Kingsbury: Otherland Publications, 57-72.

\footnotetext{
${ }^{1}$ For a more general discussion of Asian Australian women's fiction, see for example Ferrier 2017 and Ommundsen 2017.

${ }^{2}$ For a discussion of the range of meaning of 'Chinese' in diaspora, see Ang 2001 and Ommundsen 2017. On the slippage between 'Chinese' and 'Asian', see in particular Khoo 2007.

${ }^{3}$ For further discussion of the Chinese Australian press at the turn of the $20^{\text {th }}$ century, see Huang and Ommundsen 2015 and Huang and Ommundsen 2016.

4 多妻毒 ( The Poison of Polygamy) was published in 53 instalments between 8 June 1909 and 16 December 2010. An English translation, by Ely Finch, will be published by Sydney University Press in 2019. For my
} 
understanding of this text I am indebted to former and current PhD students, especially Huang Zhong and $\mathrm{Lu}$ Qiuping. For a detailed discussion of the novel and its context, see Huang and Ommundsen 2016.

${ }^{5}$ On the comparison of Western and Chinese men in terms of models of masculinity, see Louie 2002 and Huang 2012. On the impact of Western literature and culture on Chinese conceptions of love, see Pan 2015. For the development of Chinese feminism, and Chinese feminist writing, see for example Hong Fincher 2018 and Schaffer and Song, 2014.

${ }^{6}$ See Zhong 2001. For a different account of mixed marriages in the Chinese Australian community in the 1990s, see Louie 2001. 